\title{
Impact of High Temperature on Antioxidant Enzymes during Reproductive Phase in Rice Cultivars
}

\author{
Shabnam Khan*, Arti Guhey and V.B. Kuruwanshi \\ Department of Plant Physiology, Agricultural Biochemistry, Medicinal and Aromatic plants, \\ Indira Gandhi Krishi Vishwavidyalaya, Raipur-492 012, Chhattisgarh, India \\ *Corresponding author
}

\section{A B S T R A C T}

\begin{tabular}{|l|}
\hline Ke y w o r d s \\
Antioxidant enzymes, \\
Rice, Ascorbate \\
peroxidase, Catalase, \\
Heat stress, Hydrogen \\
peroxide.
\end{tabular}

Keywords

Antioxidant enzymes, Rice, Ascorbate peroxidase, Catalase, peroxide.

\section{Introduction}

Rice is the most diverse cereal crop in the world, it is poorly adapted to high temperature and flowering (anthesis) is the most heat sensitive stage (Farrel et al., 2006). Exposure of rice crop to heat stress at least during a part of its growth stage may drastically reduce the yield. High temperature at reproductive stage can decrease rice yield due to reduced pollen viability and increased spikelet sterility. At the cellular level, it has been observed in many crops that the level of active oxygen species (AOS) like superoxide radicle, hydrogen peroxide, single oxygen and hydroxyl radicle and antioxidant enzymes like superoxide dismutase, catalase and peroxidase increase when plants are exposed to high temperature (Bowler et al., 1992) and also when the plants undergo the shift from vegetative to reproductive stage (Gielis et al., 1999). The present study was undertaken to assess the contribution of different $\mathrm{H}_{2} \mathrm{O}_{2}$ scavenging enzymes in detoxification under two different stressful environment experienced by the same plants.

\section{Materials and Methods}

Seeds of 20 rice cultivars were sown in pots with $2 \mathrm{~kg}$ of autoclaved soil. Fertilizers @ 60 $\mathrm{mg}$ urea, $30 \mathrm{mg}$ superphosphate and $60 \mathrm{mg}$ potash per plot were applied at the time of sowing. The plants were transplanted 30 DAS 
and three plants are maintained per plot. All plants were maintained at $28 / 25^{\circ} \mathrm{C}$ at $75 \pm 5 \%$ relative humidity. At 55 DAT (Primordia initiation stage) one set of plot was transferred to a growth chamber under condition of elevated temperature $35 / 28^{\circ} \mathrm{C}$ (high temperature exposure) and other was kept in growth chamber maintained at $26 / 22^{0} \mathrm{C}$ (normal for rice cultivar). First sampling was done after 10 days of treatment followed by 5 days interval in the second samples. Fully expanded leaf was taken for extraction of the enzyme from stressed and control plants.

\section{Enzyme assay}

Leaves were cut into small pieces and ground in potassium phosphate buffer $(1: 25 \mathrm{w} / \mathrm{v}, \mathrm{pH}$ 7.0) containing $0.2 \mathrm{mmol} \mathrm{L}^{-1}$ ascorbate and $1 \%$ PVPP. The ground tissue was spun at $13,000 \mathrm{~g}$ at $9^{0} \mathrm{C}$ for $10 \mathrm{~min}$. the supernatant was collected and used for enzyme assay. All operations were carried out at $4^{0} \mathrm{C}$. Total soluble protein was measured using BGA as a standard (Lowry et al., 1951). The peroxidase (POX) activity was estimated by recording the decrease in ascorbate $\left(\varepsilon=2.8 \mathrm{~m} \mathrm{M}^{-1} \mathrm{~cm}^{-1}\right)$ content at $290 \mathrm{~nm}$, as ascorbate was oxidized (Nakano et al., 1981). Catalase (CAT) was assessed by measuring the disappearance of $\mathrm{H} 2 \mathrm{O} 2\left(\varepsilon=39.4 \mathrm{~m} \mathrm{M}^{-1} \mathrm{~cm}^{-1}\right.$ ) (Aebi et al., 1984). SOD activity was assessed by following method of (Dhindsa et al., 1981). SOD was measured by spectrophotometer at $560 \mathrm{~nm}$ wavelength.

\section{Results and Discussion}

The data pertaining to the effect of high temperature on CAT, SOD, POX activity in rice cultivars is presented in Table 1 and Figure 1.

Catalase (CAT) was found to be significantly different among different temperature treatments. Catalase activity decreased in plants exposed to long period of heat stress. In the first stage after heat stress, the cultivars IURON 13-11, R 2032-50-6-1-134, OR 23761, 1RH-103 and R 1138-668-3-533-1 experienced increased catalase activity to degrade $\mathrm{H}_{2} \mathrm{O}_{2}$ production which was not maintained subsequently.

During long period of stress, level of catalase has been shown to drop in a wide range of species. Water deficit indicated oxidative stress in rice plants has also been reported to result in decreased level of SOD, APX, POX and CAT with catalase activity being maximally affected (Bio et al., 2012). An increase in catalase activity under normal temperature in IURON 13-11, OR 2376-1, $1 \mathrm{RH}-103$ and R 1138-668-3-533-1 before flowering indicates that stressful condition generated due to the transition of the plant towards the reproductive stage is overcome by the increased antioxidant activity of catalase.

It has been reported that during the transition from vegetative to reproductive phase, the level of active oxygen species and antioxidant enzymes increases suggested that plants undergo stressful conditions during flowering process (Lui et al., 2013). In IURON 13-11, R 2032-50-6-1-134, OR 2376-1 and 1RH-103 flowering initiated 73 days after transplanting under normal conditions. This was followed with the increase in catalase activity which shows that $\mathrm{H}_{2} \mathrm{O}_{2}$ which may be produced under such conditions scavenged by catalase enzyme.

Peroxidase (POX) activity increased in all genotypes under high temperature. Level of enzyme activity was higher in R-GM-AS-42 and R 2196-1150-1-412-1 at all stages of growth. Thus it conclusively support that both peroxidases compliment towards the breakdown of $\mathrm{H}_{2} \mathrm{O}_{2}$ in protection against the oxidative damage. 
Table.1 Effect of high temperature on CAT, SOD, POX activity in rice cultivars

\begin{tabular}{|c|c|c|c|c|c|c|}
\hline \multirow{2}{*}{\begin{tabular}{|l} 
Accessions \\
Temperature
\end{tabular}} & \multicolumn{2}{|c|}{$\begin{array}{c}\text { CAT } \\
\left(\mathrm{H}_{2} \mathrm{O}_{2}^{-1} \mathrm{~min}^{-1} \mathrm{~g}^{-1}\right)\end{array}$} & \multicolumn{2}{|c|}{ SOD $\left(g^{-1}\right)$} & \multicolumn{2}{|c|}{$\begin{array}{c}\text { POX } \\
\left(\mathrm{H}_{2} \mathrm{O}_{2}^{-1} \mathrm{~min}^{-1} \mathrm{~g}^{-1}\right)\end{array}$} \\
\hline & $26^{\circ} \mathrm{C}$ & $35^{0} \mathrm{C}$ & $26^{0} \mathrm{C}$ & $35^{0} \mathrm{C}$ & $26^{0} \mathrm{C}$ & $35^{0} \mathrm{C}$ \\
\hline IURON 13-5 & 10.0 & 60.0 & 0.46 & 0.77 & 1.60 & 2.35 \\
\hline IURON 13-11 & 117.5 & 85.0 & 0.65 & 0.81 & 0.20 & 0.80 \\
\hline R $1625-1204-1-754-1$ & 45.0 & 55.0 & 0.42 & 0.24 & 0.55 & 1.55 \\
\hline R 1661-605-84-1 & 31.0 & 52.5 & 0.45 & 1.25 & 0.45 & 1.20 \\
\hline R 1896-268-1-80-1 & 53.0 & 72.5 & 1.10 & 1.55 & 0.25 & 1.20 \\
\hline R 2032-506-1-134-1 & 54.0 & 28.0 & 1.46 & 0.26 & 0.55 & 1.35 \\
\hline R $1762-780-1-242-1$ & 60.5 & 71.0 & 0.91 & 1.28 & 0.65 & 1.50 \\
\hline R 2196-1150-1-472-1 & 44.5 & 47.0 & 1.43 & 1.78 & 0.45 & 2.20 \\
\hline R-GM-AS-42 & 30.5 & 47.0 & 1.32 & 1.56 & 1.50 & 2.70 \\
\hline R1656-430-10-1965-1 & 41.5 & 51.0 & 0.70 & 1.12 & 0.30 & 1.0 \\
\hline R2164-1069-440-1 & 31.0 & 42.0 & 0.67 & 1.56 & 1.20 & 2.40 \\
\hline R 2196-1150-1-472-1 & 52.0 & 66.5 & 1.47 & 1.57 & 0.20 & 2.40 \\
\hline OR2376-1 & 55.0 & 32.5 & 1.32 & 0.65 & 0.40 & 1.40 \\
\hline Gopalbhog & 60.0 & 72.5 & 0.65 & 1.11 & 1.65 & 2.0 \\
\hline IRH 103 & 81.5 & 28.0 & 0.53 & 0.11 & 0.45 & 1.30 \\
\hline R1138-668-3-533-1 & 73.0 & 39.0 & 0.42 & 0.10 & 1.55 & 2.35 \\
\hline Indira Sona & 35.5 & 63.5 & 1.36 & 2.13 & 0.50 & 0.80 \\
\hline R RF 75 & 22.5 & 53.5 & 1.51 & 2.13 & 0.30 & 1.70 \\
\hline R1656-3173-1-415-1 & 43.0 & 61.0 & 1.79 & 1.68 & 0.25 & 1.70 \\
\hline R2093-1536-1-660-1 & 52.50 & 62.5 & 0.59 & 1.68 & 0.70 & 1.70 \\
\hline CD at $5 \%$ & 32.24 & 14.98 & 0.22 & 0.96 & 2.86 & 3.29 \\
\hline
\end{tabular}

Fig.1 Effect of high temperature on CAT, SOD, POX activity in rice cultivars

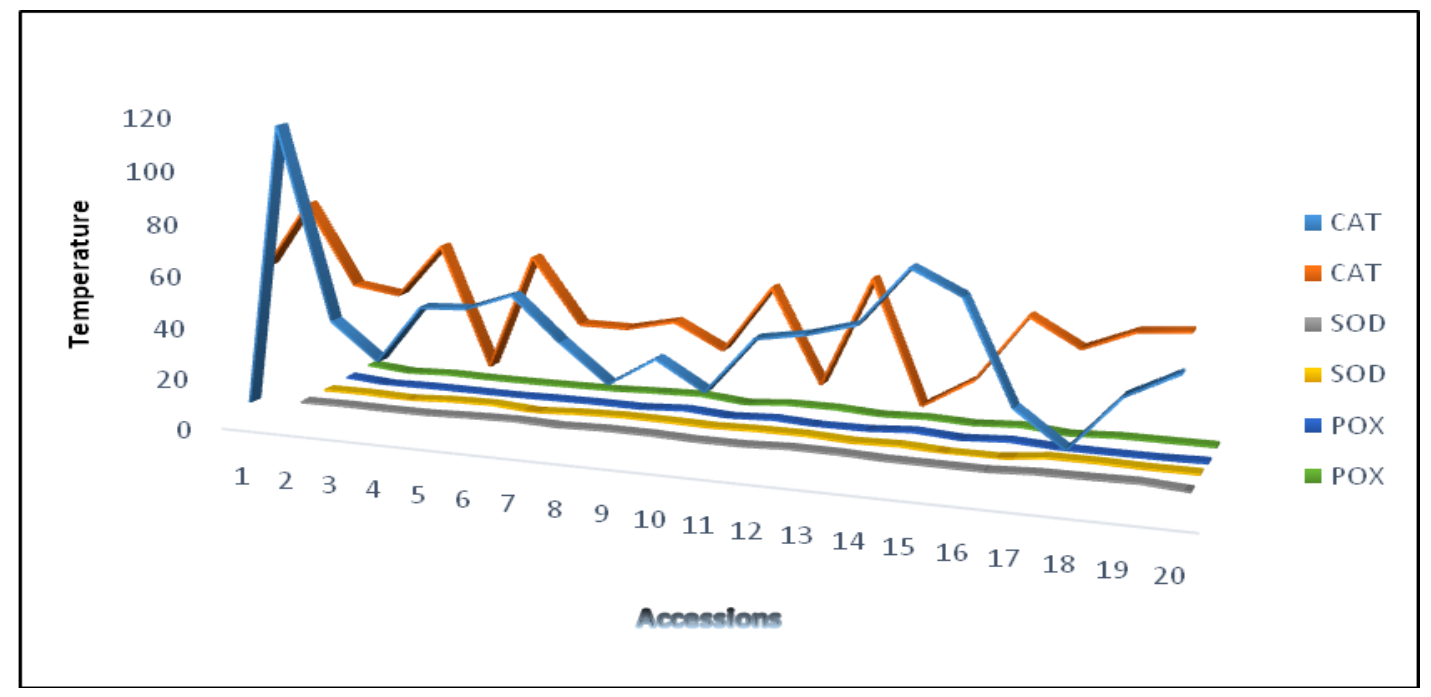

Superoxide dismutase (SOD) activity at control ranged from 0.042 to 1.79 . The higher SOD enzyme activity was recorded in accession R 1656-3173-415-1. SOD activity increased in almost all accession in higher temperature except accessions R 1625-1204-
1-754-1, R 2032-506-1-134-1, 1RH-103 and R 1138-668-3-553-1 overexpression of SOD in plants affected a number of physiological phenomenon which included the removal of $\mathrm{H}_{2} \mathrm{O}_{2}$, oxidation of toxic reductants, biosynthesis and degradation of lignins in cell 
walls, auxin catabolism, defensive response to wounding and some respiratory process (Lui et al., 2012).

The interactive effect of high temperature and flowering stress on catalase activity which decreases under this conditions remain unclear. In the heat stressed plants which flower earlier than control condition. The peroxidase scavenging system has an overriding influence over catalase in detoxifying $\mathrm{H}_{2} \mathrm{O}_{2}$.

The differential response of antioxidant enzymes as a consequence of oxidative stress under high temperature and transition to reproductive phase leads us to propose that (a) peroxidase enzymes detoxify $\mathrm{H}_{2} \mathrm{O}_{2}$ under heat stress condition (b) catalase enzyme scavenges $\mathrm{H}_{2} \mathrm{O}_{2}$ during the shift in the vegetative to reproductive stage.

\section{References}

Aebi, H. 1984. Catalase in vitro. Method Enzymol. 105: 121-126.

Bio, H.S., Ping, Z.Y., Feng, Z.D., Qing, L.X. and Jing, X. 2012. Evaluation of heat resistance in hybrid rice. Chinese $\mathrm{J}$. Rice Sci., 26(6): 75-756.

Bowler, C.M., Van Montagu, M. and Inze, D. 1992. Superoxide dismutase and stress tolerance. Ann. Rev. Plant Physiology. Plant Mol. Biol., 43: 83-116.

Dhindsa, R.H., Dhindsa, R.P. and Thorpe,
T.A. 1981. Leaf senescence correlated with increased level of membrane permeability, lipid peroxidation and decreased level of SOD and CAT. J. Exp. Bot., 32: 93-101.

Farrell, T., Fox, M., Williams, L. and Fukai, S. 2006. Genotype variation for cold tolerance during reproductive development in rice: screening with cold air and cold water. Field crops Res., 98: 178-194.

Gielis, J., Geotghebeur, P. and Debergh, P. 1999. Physiological aspects and experimental reversion of flowering in Fagesiamurrliae (Poaceae). Syst.Geogr. Pant.68: 147-158.

Liu, J., Zhang, F., Zhou, J., Chen, F., Wang, B. and Xie, X. 2012. Phytochrome B control of total leaf area and stomatal density affects drought tolerance in rice. Pl. Mol. Bio., 78: 289-300.

Liu, Q., Wu, X., Ma, J., Li, T., Zhou, X. and Guo, T. 2013. Effect of high air temperature on rice grain quality and yield under field condition. Agronomy Journal, 105(2): 446-454.

Lowry, O.H., Rosenbrough, N.J., Farr, A.L. and Randall, H.J. 1951. Protein measurement with the folin phenol reagent. J. Bio. Chem, 193: 265-275.

Nakano, Y. and Abada, K.1981. Hydrogen peroxide is scavenged by ascorbate peroxidase in spinach chloroplast. Plant Cell Physiol., 22: 867-880.

\section{How to cite this article:}

Shabnam Khan, Arti Guhey and Kuruwanshi, V.B. 2017. Impact of High Temperature on Antioxidant Enzymes during Reproductive Phase in Rice Cultivars. Int.J.Curr.Microbiol.App.Sci. 6(11): 1099-1102. doi: https://doi.org/10.20546/ijcmas.2017.611.129 